\title{
Factors Affecting the Financial Performance of Jordanian Insurance Companies Listed at Amman Stock Exchange
}

\author{
Dr. Amal Yassin Almajali \\ Departmen of administration and financial sciences \\ AlBalqa Applied University, karak, Jordan \\ E-mail: Ah1962kh@yahoo.com \\ Sameer Ahmed Alamro \\ Departmen of administration and financial sciences \\ AlBalqa Applied University, karak, Jordan \\ E-mail: Ah1962kh@yahoo.com
}

Yahya Zakarea Al-Soub

Income Tax Department and Sales Department of Finance in Jordan

E-mail: Ah1962kh@yahoo.com

Received: March 7, 2012 Accepted: March 30, $2012 \quad$ Published: April 1, 2012

doi:10.5296/jmr.v4i2.1482 URL: http://dx.doi.org/10.5296/jmr.v4i2.1482

\begin{abstract}
This study aimed at investigating the factors that mostly affect financial performance of Jordanian Insurance Companies. The study population consisted of all insurance companies' enlisted at Amman stock Exchange during the period (2002-2007) which count (25) insurance company. The data collected was analysed by using a number of basic statistical techniques such as T-test and Multiple- regression. The results showed that the following variables (Leverage, liquidity, Size, Management competence index) have a positive statistical effect on the financial performance of Jordanian Insurance Companies. The researcher recommended that a high consideration of increasing the company assets will lead
\end{abstract}


to a good financial performance and there is a significant need to have highly qualified employees in the top managerial staff.

Keywords: Financial performance, Stock exchange, Factors affecting. 


\section{Introduction}

Company performance is very essential to management as it is an outcome which has been achieved by an individual or a group of individuals in an organization related to its authority and responsibility in achieving the goal legally, not against the law, and conforming to the morale and ethic.

Performance is the function of the ability of an organization to gain and manage the resources in several different ways to develop competitive advantage (Iswatia, \& Anshoria, 2007). There are two kinds of performance, financial performance and non-financial performance. Financial performance emphasizes on variables related directly to financial report. Company's performance is evaluated in three dimensions. The first dimension is company's productivity, or processing inputs into outputs efficiently. The second is profitability dimension, or the level of which company's earning are bigger than its costs. The third dimension is market premium, or the level of which company's market value is exceeding its book value (Walker, 2001)

Performance is a difficult concept, in terms of both definition and measurement. It has been defined as the result of activity, and the appropriate measure selected to assess corporate performance is considered to depend on the type of organization to be evaluated, and the objectives to be achieved through that evaluation. Researchers in the strategic management field have offered a variety of models for analyzing financial performance. However, little consensus has emerged on what constitutes a valid set of performance criteria. For instance, researchers have suggested that studies on financial performance should include multiple criteria analysis. This multidimensional view of performance implies that different models or patterns of relationship between corporate performance and its determinants will emerge to demonstrate the various sets of relationships between dependent and independent variables in the estimated models(Ostroff and Schmidt, 1993)

\section{Statement of the Problem}

The subject of financial performance has received significant attention from scholars in the various areas of business and strategic management. It has also been the primary concern of business practitioners in all types of organizations since financial performance has implications to organization's health and ultimately its survival. High performance reflects management effectiveness and efficiency in making use of company's resources and this in turn contributes to the country's economy at large. (Naser, and Mokhtar, 2004)

In Jordan there was a good performance of many sectors such as banking sector, the insurance sector didn't react to the growth of Jordanian economy. The overall financial performance of insurance companies in Jordan is somehow weak expect for some companies which accomplished some revenues. This study tries to investigate the weakness in the overall financial performance of insurance companies. The study's main objective then could be summarized in identifying the factors affecting Jordanian insurance companies' financial performance.

Therefore, this study seeks to answer the following questions: 
What are the basic factors affecting financial performance of Jordanian Insurance Companies?

What is the level of financial performance for Jordanian insurance companies?

\section{The Importance of the Study}

The study importance emerges from the fact that insurance sector plays a significant role in enhancing the country economy, and providing critical services for people in Jordan, the current study will empirically implement a comprehensive analytical framework of financial performance in the case of Jordan insurance sector. The study will also examine the impact of key determinants of firms' financial performance.

Other importance of this study could be summarized as the following:

In Jordan, a few researches have been investigated factors affecting Jordanian insurance companies' financial performance, so the current study will be a base for other studies in the same field, and it will help in adding value to this subject.

Another importance of this study derived from distinguishing between financial and non-financial drivers of Jordanian insurance companies' financial performance.

The current study will also provide a comprehensive framework and literature about of firm financial performance, and the factors influencing it in the case of Jordanian insurance companies.

Finally the current study will identify the effect of Leverage, liquidity, Age, Size, Management competence index, or other not identified variables on Jordanian insurance companies'

\section{Aim and Objectives}

The main aim of this study is to investigate the factors that mostly affect financial performance of Jordanian Insurance Companies. This aim will be achieved by the following objectives:

To identify the effect of Leverage, Age, Size, liquidity, Management competence index on the financial performance of Jordanian insurance companies.

To provide some conclusions and recommendations for top management and decision makers at insurance companies to deal with variables that affect financial performance In order to enhance their company financial performance.

To provide the local libraries with scientific material dealing with variables that affect financial performance on Jordanian insurance companies'

\section{Literature Review}

\subsection{Insurance in Jordan}

The Jordanian insurance sector came into existence primarily in 1946 when an insurance 
agency affiliated with the Egyptian Orient Insurance Company was established. Prior to that, insurance had been limited to insurance on letters of credit that required cover on land or marine transport. This cover was provided by the Ottoman Bank through Eagle Star Company in London. In 1956, the first Association for Insurance Companies was established as the authority responsible for regulating the sector (insurance commission ,2007).

The insurance sector in Jordan consists of 26 licensed insurers (as of 2006 year-end), of which one is specialized in life insurance, 7 are specialized in general insurance, and the remaining 18 are engaged in both life and general insurance (insurance commission, 2007).

The large number of insurance companies in the market coupled with the severely underdevelopment of the sector has led to an overcrowded market, with the leader in terms of market share of premiums written claiming a mere $8.9 \%$ of the total, and the average market share for the companies in the sector standing at 3.8\% in 2006 (insurance commission ,2007).

In contrast, the sole insurer specializing in life insurance alone, the American Life Insurance Company, claimed $49.9 \%$ of total life premiums written in 2006 .

The market contains 33 loss adjusters, 50 brokers, 7 insurance advisors, 10 actuaries and 385 agents.(insurance commission,2007)

\subsection{Firm Performance}

Company performance is very essential to management as it is an outcome which has been achieved by an individual or a group of individuals in an organization related to its authority and responsibility in achieving the goal legally, not against the law, and conforming to the morale and ethic. Performance is the function of the ability of an organization to gain and manage the resources in several different ways to develop competitive advantage. There are two kinds of performance, financial performance and non-financial performance (Hansen and Mowen, 2005).

The literature usually distinguishes between two types of firm performance, financial or economic performance and innovative performance. Financial or economic performance is often expressed in terms of growth of sales, turnover, employment, or stock prices (Havnes and Senneseth 2001), whereas innovative performance is generally expressed in terms of expenditures, patents, percentage of innovative sales, or self-reported (results of) innovations (Oerlemans et al. 2001, Hagedoorn and Cloodt 2003). Although both types of performance are often inter-related (Damanpour and Evan 1984), the literature often uses both types of performance as separate concepts or only focuses on one of the two. (Knoben and Oerlemans,2006)

Company performance is the measurement for what had been achieved by company which shows good condition for certain period of time. The purpose of measuring the achievement is to obtain useful information related to flow of fund, the use of fund, effectiveness, and efficiency. Besides, the information can also motivate the managers to make the best decision.

\subsection{Measures of Financial Performance}

There have been various measures of financial performance. For example return on sales 
reveals how much a company earns in relation to its sales, return on assets determines an organization's ability to make use of its assets and return on equity reveals what return investors take for their investments. The advantages of financial measures are the easiness of calculation and that definitions are agreed worldwide. Traditionally, the success of a manufacturing system or company has been evaluated by the use of financial measures (Tangen, 2003).

(Berger, et al.1995) contend that the factors underpinning the operational performance of financial services firms are often difficult to discern because of the intangible nature of outputs and the lack of transparency over resource allocation decisions. Nonetheless, insights from the financial economics literature, such as those provided by agency theory, can contribute important insights into the determinants of operational performance in financial services firms. For instance, agency theory articulates that relationships between owners of firms (principals) and managers (agents) are maintained by contracts (Jensen, 1990). As the separation between ownership and control diverges due to corporate growth, contracts have to be introduced to ensure the alignment of owners' and managers' economic interests. As a result, operational performance will be a function of the effectiveness of contractual mechanisms in attracting, retaining and controlling managerial talent in ways that maximize owners' wealth.

\subsection{The Primary Ratios}

The primary ratios used for analyzing the performance of a company can be categorized into five groups:

\section{.Liquidity ratios}

\section{.Asset management ratios \\ .Debt management ratios \\ .Profitability ratios}

.Market value ratios

These ratios can be combined to determine the rate of return for a company and its owners and the rate at which the company can grow the sustainable rate of growth. By adding data about the company's stock market performance, the analyst can gain insight into how financial markets view the company's performance (Harrington, 1989)

\section{Factors Affect Financial Performance of Companies}

Empirical literature examines how financial and non-financial factors, such as leverage, liquidity, size, age, and Management competence index have an influence on the firms' financial performance and growth. The researcher has chosen these factors because they are the most appropriate ones for Jordanian context among many factors affecting the financial performance. On the other hand, these factors can be easily measured by using the data that is afford by Jordanian insurance companies. 


\section{A- Leverage}

Debt leverage is measured by the ratio of total debt to equity (debt/equity ratio). It shows the degree to which a business is utilizing borrowed money. Companies that are highly leveraged may be at risk of bankruptcy if they are unable to make payments on their debt; they may also be unable to find new lenders in the future. Leverage is not always bad, however; it can increase the shareholders' return on their investment and make good use of the tax advantages associated with borrowing.

\section{B- Liquidity}

Liquidity refers to the degree to which debt obligations coming due in the next 12 months can be paid from cash or assets that will be turned into cash. It is usually measured by the current assets to current liabilities (current ratio). It shows the ability to convert an asset to cash quickly and reflects the ability of the firm to manage working capital when kept at normal levels. A firm can use liquid assets to finance its activities and investments when external finance is not available or it is too costly. On the other hand, higher liquidity would allow a firm to deal with unexpected contingencies and to cope with its obligations during periods of low earnings. (Liargovas, and Skandalis, 2008)

\section{C- Company Size}

The size of the firm affects its financial performance in many ways. Large firms can exploit economies of scale and scope and thus being more efficient compared to small firms. In addition, small firms may have less power than large firms; hence they may find it difficult to compete with the large firms particularly in highly competitive markets. On the other hand, as firms become larger, they might suffer from inefficiencies, leading to inferior financial performance. Theory, therefore, is equivocal on the precise relationship between size and performance (Majumdar, 1997).

\section{D- Company Age}

Several earlier studies (Batra, 1999, Lumpkin \& Dess, 1999) argued that firm age has an influence on its performance.(Sorensen \& Stuart ,2000) argued that organizational inertia operating in old firms tend to make them inflexible and unable to appreciate changes in the environment. Newer and smaller firms, as a result, take away market share in spite of disadvantages like lack of capital, brand names and corporate reputation with older firms.(Kakani., Saha,, and Reddy, 2001)

Regarding firm age, older firms are more experienced, have enjoyed the benefits of learning, are not prone to the liabilities of newness, and can, therefore, enjoy superior performance. Older firms may also benefit from reputation effects, which allow them to earn a higher margin on sales. On the other hand, older firms are prone to inertia, and the bureaucratic ossification that goes along with age; they might have developed routines, which are out of touch with changes in market conditions, in which case an inverse relationship between age and profitability or growth could be observed.(Liargovas, and Skandalis, 2008) 


\section{E- Management Competence Index}

Is a multidimensional concept and a number of well documented attempts have been made in the literature to define it. More specifically, the popularity of the term competence can be attributed to (Boyatzi, 1982). In “The Competent Manager"(Boyatzi ,1982) defines competence as "an underlying characteristic of a person", stating it could be, "motive, trait, skill, aspect of one's self-image or social role, or a body of knowledge which he or she uses"(Woodruffe, 1993) points out, that this definition leaves the term open to a multitude of interpretations and argues that the term 'competence' can be used to refer to a 'set of behaviors, skills, knowledge and understanding which are crucial to the effective performance of a position'. (Nordhaug and Gronhaug ,1994) interpret competence as "work-related knowledge, skills and abilities" while(Rees ,2003) argues that there has been an enormous diversity of interpretation of the term, 'competence', and no agreed definition.(Hamel and Prahalad ,1994) define competence as a bundle of skills and technologies that enable company to provide benefits for customers rather than a single skill or technology.

\section{Previous Studies}

A study for (Lee, 2008) titled: "Ownership Structure and Financial Performance: Evidence from Panel Data of South Korea".

The study examined the effect of equity ownership structure on firm financial performance in South Korea. It focused on the role of two main dimensions of the ownership structure: Ownership concentration (i.e., the distribution of shares owned by majority shareholders) and identity of owners (especially, foreign investors and institutional investors). Using panel data for South Korea in 2000-2006, the study found that firm performance measured by the accounting rate of return on assets generally improved as ownership concentration increases, but the effects of foreign ownership and institutional ownership are insignificant. The study also found that there exists a hump-shaped relationship between ownership concentration and firm performance, in which firm performance peaks at intermediate levels of ownership concentration. The study provided some empirical support for the hypothesis that as ownership concentration increases, the positive monitoring effect of concentrated ownership first dominates but later is outweighed by the negative effects, such as the expropriation of minority shareholders. The empirical findings shed light on the role ownership structure plays in corporate performance, and thus offer insights to policy makers interested in improving corporate governance systems in an emerging economy such as South Korea.

A study for(Liargovas \& Skandalis ,2008) titled: "Factors affecting Firms Financial Performance: the Case of Greece".

The purpose of this study is to empirically implement a comprehensive analytical framework of financial performance in the case of Greek industrial firms during the period 1997-2004. The paper examined the impact of key determinants of firms' financial performance. The study distinguished between financial and non financial drivers of firm performance. The study results showed that leverage, export activity, location, size and the index for 
management competence significantly affect firm performance in Greece. The results indicated that profitable firms in Greece are large, young, exporting firms with a competitive management team, which have an optimal debt-equity ratio and use their liquidity to finance their investments.

A study for (Prasetyantoko \&Parmono,2008) titled: "Determinants of Corporate Performance of Listed Companies in Indonesia"

Which was basically concerned with the factors determining corporate performance of listed companies in Indonesia, especially due to the 1997 financial crisis? The main result was fairly interesting in which firm size is positively related to firm profitability, but it was not related to market capitalization. It means that firm size is matter on the fundamental value of the firms, but it should not be important variable for market value of the firms. By employing panel data of 238 listed companies in Jakarta Stock Exchange (JSX) in the period 1994 2004 as the sample, the study also found that macro factors are more important variables inducing firm Performance, rather than firm-specific factors. It could be due to the 1997 great crisis. The results also showed that ownership factor matters on firm performance by the evidence that firms with majority foreign ownership have much higher performance in both measurements namely return on asset (ROA) and market capitalization growth than domestically-owned firms.

A study for (Antoniou et al, 2007) titled: "The Determinants of Capital Structure: Capital Market Oriented versus Bank Oriented Institutions".

This study investigated how firms operating in capital market oriented economies (the United Kingdom and the United States) and bank oriented economies (France, Germany and Japan) determine their capital structure. Using panel data and a two-step system-GMM procedure, the study found that the leverage ratio is positively affected by the tangibility of assets and the size of the firm, but declines with an increase in firm profitability, growth opportunities and share price performance in both types of economies. The leverage ratio is also affected by the market conditions in which the firm operates. The degree and effectiveness of these determinants are dependent on the country's legal and financial traditions. The results also confirm that firms have target leverage ratios, with French firms being the quickest in adjusting their capital structure towards their target level, and the Japanese are the slowest. Overall, the capital structure of a firm is heavily influenced by the economic environment and its institutions, corporate governance practices, tax systems, the borrower-lender relationship, exposure to capital markets, and the level of investor protection in the country in which the firm operates.

A study for (Tarawneh ,2006) titled: "A Comparison of Financial Performance in the Banking Sector: Some Evidence from Omani Commercial Banks".

The purpose of this study is to classify the commercial banks in Oman in cohesive categories on the basis of their financial characteristics revealed by the financial ratios. Total of five Omani commercial banks with more than 260 branches were financially analyzed, and simple regression was used to estimate the impact of asset management, operational efficiency, and 
bank size on the financial performance of these banks.

The study found that the bank with higher total capital, deposits, credits, or total assets does not always mean that has better profitability performance.

\section{Study Population and Sample}

The study population consisted of all insurance Companies' enlisted at Amman stock Exchange during the period (2002-2007) which count (25) insurance company. The researcher took all of them as a study sample.

\section{Methods of Collecting Data}

The researcher depended on secondary sources which include books Articles, relevant literature, Jordanian insurance companies financial statement and reports, and Amman Stock Exchange in order to collect the scientific content of the theoretical framework of the study and to explain the basic concepts of the study. The collected data focused into the following variables:

\section{. Company Leverage}

. Company liquidity

. Company Age

. Company Size

. Company management competence index

. Financial performance through calculating (ROA)

\section{Data Treatment}

Depend on the study model the regression analysis was used to investigate the impact of independent variables on dependent variable. The following explain the method used for calculating dependent and independent variables:

A measure was used to evaluate the financial performance that is the Return on assets (ROA): ROA is one of the most widely used financial models for performance measurements and it was developed by Dupont in 1919. ROA determines a firm's ability to make use of its assets (Tangen, 2003). One of the previous study (Agiomir giannakis, et al. 2006) has used ROA as a measure of financial performance.

.Leverage as measured by the ratio of total debt to equity (debt/equity ratio)

.Liquidity ratio measured by the ratio of current assets to current liabilities

.Size as measured by the Total Assets

.Age as measured by the number of years since establishment

.Management Competence Index measured by the ratio of profit to number professional 


\section{Macrothink

.Financial performance was measured by ROA

The analysis of the data collected from Jordanian insurance companies financial statement will follow a number of basic statistical techniques in order to identify and interpret the ratings of respondents such as means, standard deviations, $\mathrm{T}$ - test for independent variable,

The degree of criticality of each factor is to be analysed by using a content analysis approach.

To answer the study questions and hypothesis the following statistical methods will be used:

.For subject of response description means and standard deviation will be used

.For hypothesis testing multiple linear regression method will be used

\section{Study Model}

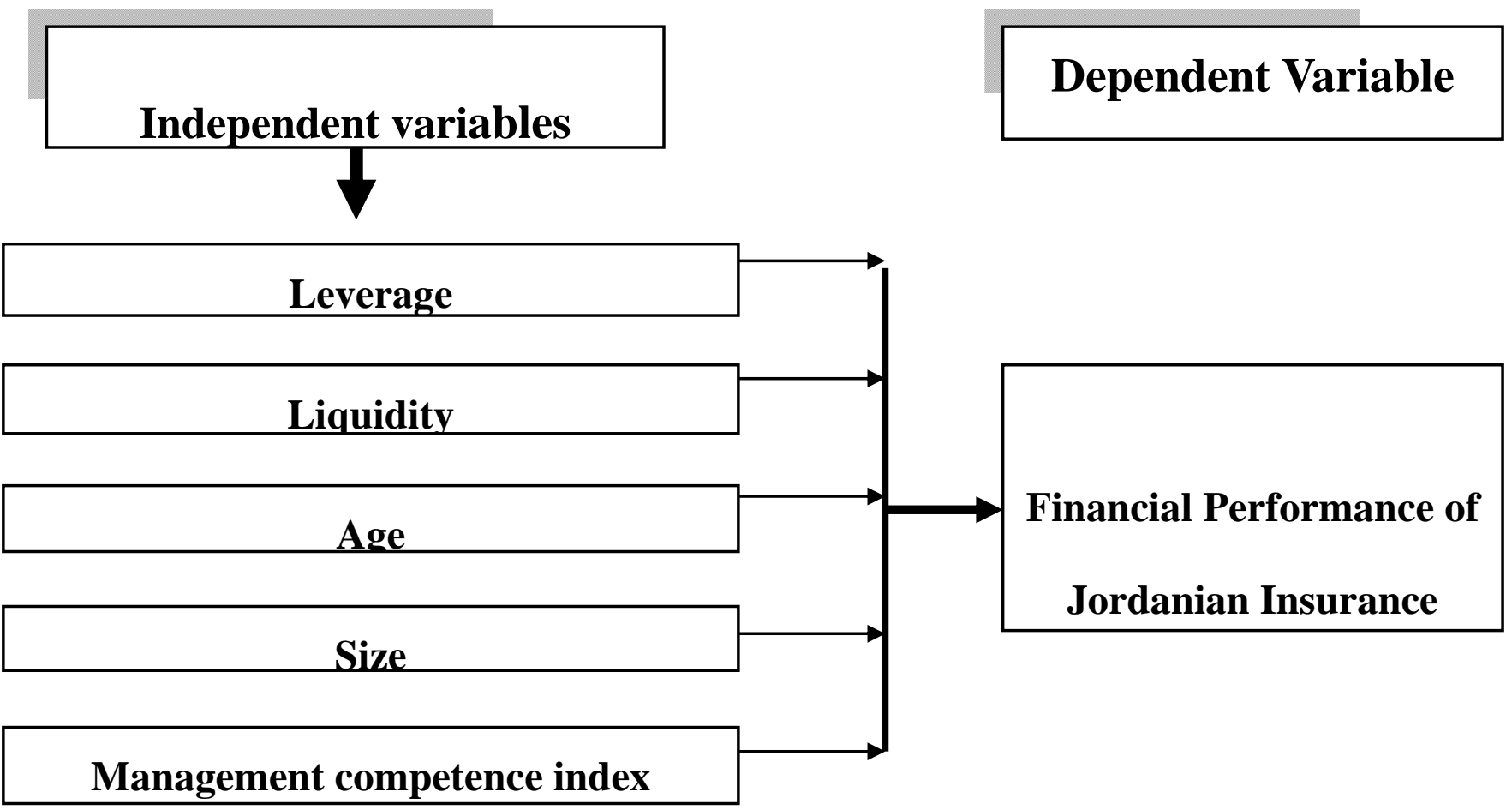

\section{Study Hypotheses}

The following null hypotheses are formulated for this study to make hypothetical answers to the study problem and its questions:

There is no significant effect for Leverage on Financial Performance (Return on assets) of Jordanian Insurance Companies.

There is no significant effect for liquidity on Financial Performance (Return on assets) of Jordanian Insurance Companies.

There is no significant effect for Age on Financial Performance (Return on assets) of Jordanian Insurance Companies. 
There is no significant effect for Size on Financial Performance (Return on assets) of Jordanian Insurance Companies.

There is no significant effect for Management competence index On Financial Performance (Return on assets) of Jordanian Insurance Compan

\section{Findings and Data analysis and Recommendations}

\subsection{Sample Profile}

Table (1) shows the sample characteristics of this study.

As shown in (1), the oldest insurance company (Jordan Insurance) was established in 1951 while the recent established company (Gerasa Insurance) was found in 1997. Regarding the employees, Jordan Insurance has the largest number of employees which is 214 . On the other hand, the lowest number (32) is found in Gerasa Insurance. Regarding the branches, Middle East Insurance has the largest network of branches which are (8). Regarding the professional, Middle East Insurance has the largest number of the professional the lowest number (1) is found in Jordan insurance and Arab union international insurance

\subsection{The Dependent Variable Question}

What is the level of financial performance for Jordanian insurance companies?

To answer this question the mean and standard deviation were calculated for the financial performance for Jordanian insurance companies for the period between (2002-2007) as shown in table (2)

Table (2) contains descriptive statistics of the dependent variable used in this study. As appeared in this table, the largest financial performance (ROA) was achieved by Jordan International Insurance Company which equal (10.708). Al-Manara Insurance Company has got the lowest financial performance (ROA) which is $(-2.776)$.

- Hypotheses Testing and Results

To test multiple regression models, it is necessary to assess whether the collected data violate some key assumptions of regression models because any assumption violations can result in distorted and biased research results (Hair et al. 1998). These assumptions include Multicollinearity and Normality:

Multicollinearity can be controlled by two ways: tolerance values and values of variance inflation factor -VIF (Hair et al. 1998). High degrees of multicollinearity can result in both regression coefficients being inaccurately estimated, and difficulties in separating the influence of the individual variables on the dependent variables (Hair et al. 1998). Any variables with a tolerance value below 0.10 or with a value above 10.0 of VIF would have a correlation of more than 0.90 with other variables, indicative of the multicollinearity problem (Hair et al. 1998). Results in the table below (3) shows that Tolerance for all independent variables is more than 0.10 and Variance Inflation Factor- VIF for the independent variables 
is less than the limited valued 10.0 , so as a result we can say there is no multicollinearity between the independent variables.

Fitness of the model: the linear regression analysis of the original model reveals that the $\mathrm{R}$-square of the model is 0.37 . This means the model explains $37 \%$ of the variance in the dependent variable (table 4) The model is statistically significant as the p-value for the model is 0.000 . That is less than the limit for statistical significance limit (table 4), which is 0.10 for weak significance and 0.05 for significance. This is good; meaning the fitness of the model in explaining the performance is high.

The data were checked to verify that the assumption of multivariate normality was met. In a strict definition of a normal distribution, the skewness of the data would equal zero (Hair et al. 1998). In a practical sense, normality is defined as "a range of scores that span either side of zero". In the current study, skewness ranged from 0.19 to 0.89 as showed in table (5). Following the definition, skewness scores of the current data indicate an approximately normal distribution.

After the researcher assure that the assumptions of regression models were met, the following section deal with hypotheses testing. The following hypotheses were tested using Multiple Regression analysis and (t-test), to know if there is an impact of independent variables on the dependent variable. According to the decision rule: accept null hypothesis (H0) if the significance level $(\alpha)$ of the question is greater than 0.05 significance level, and reject (H0) if the significance $(\alpha)$ level equals or is less than 0.05 (Sekaran, 2003). As a result for this decision rule, the researcher has tested statistically the proposed hypotheses and found the following results:

The estimated equation for multiple linear regression model is:

$\mathrm{FP}=\alpha+\mathrm{b} 1 \mathrm{~L}+\mathrm{b} 2 \mathrm{Q}+\mathrm{b} 3 \mathrm{G}+\mathrm{b} 4 \mathrm{~S}+\mathrm{b} 5 \mathrm{M}+€$

Where:

FP: financial performance

L: leverage

Q: liquidity

G: age

S: size

M: management competence index

$\alpha$ : constant

b1,b2.b3,b4,b5: the parameter to be estimated

$€$ : error

The following null hypotheses are formulated for this study to make hypothetical answers to 
the study problem and its questions:

\section{Hypothesis 1}

There is no significant effect for Leverage on Financial Performance (Return on assets) of Jordanian Insurance Companies.

Using multiple regression to test the previous mentioned hypothesis, it was found that calculated $t=7.202$ (greater than the tabulated value of $t=1.98$ ) and a significance level of (.000). The null hypothesis was rejected. Thus, the leverage which was considered as one of the important factors has an impact on financial performance for insurance company. The result suggested that the insurance company should increase its concentration on borrowing and debt department and at the same time should be careful about this.

\section{Hypothesis 2}

There is no significant effect for liquidity on Financial Performance (Return on assets) of Jordanian Insurance Companies.

Since calculated t equals 3.162 (greater than the tabulated value of $t=1.98$ ), with a $(.046)$ significance level,, the null hypothesis was rejected. It found that there is significant statistical impact of liquidity on Financial Performance of insurance companies. The result suggested that the insurance companies should increase the current assets and decrease current liabilities because the positive relationship between the liquidity and financial performance.

\section{Hypothesis 3}

There is no significant effect for Age on Financial Performance (Return on assets) of Jordanian Insurance Companies.

Ho3 was accepted since the calculated t equals 1.008 (less than the tabulated value of $t=1.98$ ), with a .994 significance level. It found that the age of company has no effect on financial performance. The result suggested that the new insurance companies shouldn't pay attention to age because of the negative relationship between age of company and financial performance.

\section{Hypothesis 4}

There is no significant effect for Size on Financial Performance (Return on assets) of Jordanian Insurance Companies.

As shown in table (7), sig. is (0.000) which is less than 0.05 , and calculated t equals 6.509 (greater than the tabulated value of $t=1.98$ ). So the null hypothesis was rejected. So that the size for insurance companies was considered an effective factor that impact on financial performance. The result suggested that the companies should increase their assets volumes in order to increase their financial performance because the positive relationship between size and financial performance.

\section{Hypothesis 5}

There is no significant effect for Management competence index on Financial Performance 
(Return on assets) of Jordanian Insurance Companies.

As shown in table (7), a calculated value of $\mathrm{t}=3.861$ (greater than the tabulated value of $\mathrm{t}=$ 1.98 ) and the significance level is .041 which is less than 0.05 . The null hypothesis was rejected .The management competence index on insurance companies as an effective factor in impacting financial performance. The result suggested that the insurance companies should focus on employees' efficiency by choosing the employees who complete higher educations.

\section{Findings Discussion}

After testing the hypothesis and analyzing the data, it was found that:

Leverage has a significant statistical impact on Financial Performance of insurance companies. This is supported by many previous studies (Liargavas and Skandalis, 2008; Kakani et al, 2005; Bashir, 2005; Neri, 2001; Admms and Buckle, 2000) which stated that an increase in the leverage has a positive impact on their performance. In alignment with most previous studies, it was that high leverage might be beneficial, because it can improve managerial incentives and force them to invest optimally. On the other hand, highly leveraged firms may confront aggressive strategies from their less leveraged rivals and lose market share in an oligopoly product market.

Liquidity has a significant statistical impact on Financial Performance of insurance companies. This study is supported by(Chen and Wong, 2004). But it contradicts with(Adams and Buckle, 2000). Since liquidity measures the ability of managers in insurance companies to fulfill their immediate commitments to policyholders and other creditors without having to increase profits on underwriting and investment activities and liquidate financial assets. This reasoning therefore implies that high liquidity obviates the need for management to improve annual operational performance. Furthermore, high liquidity could increase agency costs for owners by providing managers with incentives to misuse excess cash flows by investing in projects with negative net present value and engaging on excessive perquisite consumption.

Company age has no significant statistical impact on Financial Performance of insurance companies. This finding is consistent with what (Liargavas and Skandalis, 2008) who found that age has no significant statistical impact on financial performance. As a result, an older, well-established company is likely to be more proficient in gathering, processing and releasing information when needed because of learning experience.

Size has a significant statistical impact on Financial Performance of insurance companies. This finding is supported by (Liargavas and Skandalis, 2008; Tarawneh, 2006; Kakani et al, 2005; Chen and Wong, 2004), who stated that the larger firm are more profitable. Hence, large firms have more resources, more accounting staff and sophisticated information systems that result in high performance. Furthermore, large companies tend to be followed by a relatively large number of financial analysts who usually rely on timely release of annual reports to confirm and revise their expectations of companies' present and future economic prospects. 
.Management competence index has a significant statistical impact on Financial Performance of insurance companies. This finding is consistent with what(Liargavas and Skandalis ,2008) and(Merikas et al 2006) have found. Hence the level of education of professionals affects the assessment of the quality of their competence and thus the company's ability to achieve future success.

\section{Recommendations}

Based on the research findings the following reachable recommendations were presented for this study:

It is positive to have high consideration of increasing the company assets. Because the size of the company is an important factor as it influences its competitive power. Small companies have less power than large ones; hence they may find it difficult to compete with the large firms particularly in highly competitive markets.

Great attention should be paid to leverage. Companies that are highly leveraged may be at risk of bankruptcy if they are unable to make payments on their debt; they may also be unable to find new lenders in the future. On the other hand, leverage can increase the shareholders' return on their investment and make good use of the tax advantages associated with borrowing.

The finding regarding age has a good indicator for new entrants to insurance industry that the age of the company has no influence on its good performance.

There is a significant need to have highly qualified employees in the top managerial staff.

\section{References}

Adams, M., \& Buckle, M. (2000). The determinants of operational performance in the Bermuda insurance market. Applied Financial Economics, 13, 133-143. http://dx.doi.org/10.1080/09603100210105030

Agiomirgiannakis, G., Voulgaris, F., \& Papadogonas, T. (2006). Financial factors affecting profitability and employment growth: the case of Greek manufacturing. Int. J. Financial Services Management, 1(2/3), 232-242.

AL-Amro, S., (2007). Factor affecting stock market prices in Amman stock exchange, unpublished MA thesis, Mu'tah university, p7.

Antoniou A, Guney, Y., \& Paudyal, K. (2008). The Determinants of Capital Structure: Capital Market Oriented versus Bank Oriented Institutions. Journal of Financial and Quantitative Analysis, 43(1), 59-92. http://dx.doi.org/10.1017/S0022109000002751

Banz, R., (1981). The relationship between return and the market value for common stocks. Journal of Financial Economics, $\quad 9(1), \quad$ 1-19. http://dx.doi.org/10.1016/0304-405X(81)90018-0

Bashir, A., (2003). Determinants of Performance in Islamic Banks Some Evidence from the Middle East Islamic Economic Studies, Vol. 11, No. 2, pp1-20 
Batra, G. (1999). Job Reallocation, the Export Market, and Firm Performance: Microeconomic Evidence. World Bank Policy and Research; Business Environment Unit; Ref, 683-26; 10(1). in Liargovas,p and Skandalis,k(2008).

Berger, P., \& Ofek; E., (1995). Diversifications effect on firm value. Journal of Financial Economics, 37, 39-65. http://dx.doi.org/10.1016/0304-405X(94)00798-6

Boyatzis, R. (1982). The Competent Manager: A Model for Effective Performance, NewYork: Wiley and sons.

Bradley M, Jarrell, G., \& Kim, E. (1984). On the existence of an optimal capital structure: theory and evidence. Journal of Finance, 39(3), 857-880. in Liargovas,p and Skandalis,k(2008).

Chen, R., \& Wong, K., (2004). The Determinants of Financial Health of Asian Insurance Companies. Journal of Risk and Insurance, 71(3), 469-499. http://dx.doi.org/10.1111/j.0022-4367.2004.00099.x

Connelly, J. Limpaphayom, P. (2006). Board Characteristics and Firm Performance: Evidence from the Life Insurance Industry in Thailand. Chulalongkorn Journal of Economics, 16(2), 101-124.

Coyne, K. P., J.D. Hall, \& P. G. Clifford, (1997). Is your Core Competence a Mirage?, McKinsey Quarterly, 1, 40-55.

Damanpour, F., \& Evan, W, (1984). Organizational innovation and performance: the problem of organizational lag. Administrative Science Quarterly Journal, 29, 392, in Knobena. j and Oerlemansab.1.a (2006).

D'Souza, J, Robert C., \& Megginson, W. (2000). Determinants of Performance Improvements in Privatized Firms: The Role of Restructuring and Corporate Governance. AFA, New Orleans

Hagedoorn, J. and. Cloodt, M, (2003). Measuring innovative performance: Is there an advantage in using multiple indicators? Research Policy, 32(8), 1365-1379, in Knobena .j and Oerlemansab.1.a (2006).

Hair, J., Anderson, R., \& Tatham, R., Black, W. (1998). Multivariate data analysis. Upper Saddle River, NJ: Prentice-Hall.

Hamel, G., \& Prahalad, C. (1994). Competing for the Future. Harward Business School Press, Boston.

Hansen, R., \& Mowen,.M (2005). Management Accounting, 7 Edition. Singapore: South-Western

Hardwick, P. (1997). Measuring cost inefficiency in the UK life insurance industry, Applied Financial Economics. Aministrative Science Quarterly, 45(1), 81 - 112. 
Harrington R., \& Wilson D. (1989). Corporate Financial Analysis. (3rd ed.), Boston: Irwin Inc., p 316

Havnes, P., \& Senneseth, K. (2001). A panel study of firm growth among SMEs in networks. Small business economics, P 293-302.in Knobena. j and Oerlemansab.1.a (2006).

Iswatia, S., \& Anshoria, M. (2007). The Influence of Intellectual Capital to Financial Performance at Insurance Companies in Jakarta Stock Exchange (JSE), Proceedings of the 13th Asia Pacific Management Conference, Melbourne, Australia.

Insurance commission. (2007). The annual report http://www.irc.gov.jo.

Jermanis, D. (2006). System of Measures for Evaluating the Financial Performance of the Company Lasko, unpublished MA thesis, University of LJUBLJANA.

Jelic, M., Briston, R., \& Aussenegg, W. (2001). The Financial Performance of Privatized Firms: evidence from Three Transition Economies. Journal of Business Finance \& Accounting, 7(4), 9-25.

Jensen, M. (1990). Performance pay and top-management incentives. Journal of Political Economy, 98, 225-264.

Kakani, R., Saha, B., \& Reddy, V. (2001). Determinants of Financial Performance of Indian Corporate Sector in the Post-Liberalization Era: An Exploratory Study. NSE Research Initiative Paper, No. 5 PP12-30

Klumpes, P., \& McCrae, M. (1999). Evaluating the Financial Performance of Pension Funds: An Individual Investor's Perspective. Journal of Business Finance \& Accounting, 26(3-4), $1-22$.

Knobena .j, \& Oerlemansab.l.a. (2006). The effects of firm relocation on firm performance, Regional Studies, p3.

Lee, S. (2008). Ownership Structure and Financial Performance: Evidence from Panel Data of South Korea. Corporate Ownership and Cntrol, 6(2), 1-30.

Liargovas,p, \& Skandalis,k. (2008). Factor affecting firms financial performance The Case of Greece, University of Peloponnese.

Lumpkin, G., \&. Dess, G. (1999). Linking two dimensions of entrepreneurial orientation to firm performance: The moderating role of environment, firm age, and industry life cycle. Journal of Business Venturing; Forthcoming;

Majumdar S. (1997). The Impact of Size and Age on Firm-Level Performance: Some Evidence from India Review of Industrial Organization, 12, 231-241.

Mathur, S., \& Alfred K. (1998). Creating Value: Shaping Tomorrow's Business Butterworth Heinemann: Oxford; in Kakani, Saha, and Reddy, (2001). 
Merikas.G., Merika.A., \& Skandalis. S. (2006). An effective index of management competence (Paper presented at the 15th Annual Conference of European Financial Management Association-EFMA, Madrid

Naser, K., \& Mokhtar, M. (2004). Determinants of Corporate Performance of Malaysian Companies, Fourth Asia Pacific Interdisciplinary Research in Accounting Conference, Singapore

Neri, M. (2001). The Determinants of capital structure and its effect on corporate performance: an econometric analysis based on 7440 US Companies MA thsis. ESLSCA business school pp1-43

Nordhaug, O., \& Gronhaug, K. (1994). Competences as Resources, 5(1), February 1994, pp. 89-103.

Oerlemans, L., \&. Meeus,H (2001). Do organizational and spatial proximity impact on firm performance? Regional Studies, 39(1). in Knobena . j and Oerlemansab.l.a (2006).

Ostroff, C., \& Schmitt, N. (1993). Configuration of Organizational Effectiveness and Efficiency, Academy of Management Journal, 36(6), 1345-1361. In (Naser, K. and Mokhtar, 2004,p6).

Pi, L., \& Timme,.G (1993). Corporate control and bank efficiency. Journal of Banking and Finance, 17, 515-530. http://dx.doi.org/10.1016/0378-4266(93)90050-N

Prasetyantoko, A., \& Parmono, R. (2008). Determinants of Corporate Performance of Listed Companies in Indonesia MPRA Paper 6777, University Library of Munich, Germany

Ramana, D. (2005). Market Value Added and Economic Value Added: Some Empirical Evidences $8^{\text {th }}$, capital market conference Indian institute of capital market.

Rees, W. (2003). International Diversification and Firm Value. European Financial Management Association.

Rejc, A., \& Slapnicar, S. (2005). Corporate Performance Measurement Systems: Empirical Evidence of Determinants. Harvard Business Review, 69(1), 131-137.

Sekaran, U. (2003). Research methods for business a skill building approach, 4th edition. John Wiley \& Sons, Inc.

Sorensen, B., \& Stuart,. E. (2000). Age, Obsolescence, and Organizational Innovation. Academy of Management Journal, 25, in (Liargovas and Skandalis ,2008,p6).

Tangen S. (2003). An overview of frequently used performance measures. International Journal of Productivity and Performance Management, 52(7), 347-354. in (Liargovas,p and Skandalis,k,2008,p24).

Tarawneh, M. (2006). A Comparison of Financial Performance in the Banking Sector: Some Evidence from Omani Commercial Banks. International Research Journal of Finance and Economics, 3, 1-22. 
Walker,d. (2001). Exploring the Human Capital Contribution to Productivity, Profitability and the Market Evaluation of the Firm, available on: http:/wwwlib.umi.com/dissertations

Woodruffe, C. (1993). What is meant by competency? Leadership and Organization Development Journal, 14(1), 29-36. http://dx.doi.org/10.1108/eb053651

Zwiebel, J. (1996). Dynamic Capital Structure under Managerial Entrenchment. American Economic Review, 86, 1197-1215. in(Liargovas and Skandalis ,2008). 


\section{MlMacrothink}

Table 1. Sample Characteristics 2012, Vol. 4, No. 2

Insurance Companies

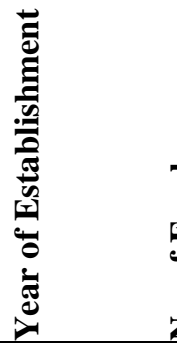

1- JORDAN INSURANCE

1951
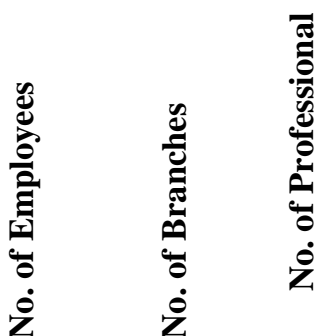

2- MIDDLE EAST INSURANCE

1962

214

2

3- THE UNITED INSURANCE

1972

139

7

13

4- GENERAL ARABIA INSURANCE

1972

5- Al-Manara Insurance

1974

6- JERUSALEM INSURANCE

7- JORDAN FRENCH INSURANCE

1975

1976

1976

56

5

8-ARAB UNION INTERNATIONAL INSURANCE

1976

60

0

4

9- DELTA INSURANCE

1980

60

1

4

10- THE HOLY LAND INSURANCE

11- YARMOUK INSURANCE \& REINSURANCE

12- Jordan \& Gulf Insurance

1980

1980

93

5

5

13- OASIS INSURANCE

14- ARAB LIFE \& ACCIDENT INSURANCE

1980

$1980 \quad 142$

15 PHILADELPHIA INSURANCE

$1980 \quad 41$

16- AL-NISR AL-ARABI INSURANCE

17 ARAB ORIENT INSURANCE

18- JORDAN INTERNATIONAL INSURANCE

19 EURO ARAB INSURANCE GROUP

$1989 \quad 125$

1996

95

1996

20- ARAB GERMAN INSURANCE

$\begin{array}{rrrr}1996 & 45 & 0 & 7 \\ 1996 & 96 & 1 & 12 \\ 1996 & 92 & 4 & 3 \\ 1996 & 70 & 5 & 10 \\ 1996 & 58 & 0 & 8 \\ 1996 & 39 & 0 & 4 \\ 1997 & 32 & 0 & 6\end{array}$


Table 2. Standard deviation for the financial performance (ROA) for Jordanian insurance companies for the period between (2002-2007)

\begin{tabular}{lll}
\hline Company Name & Mean $100 \%$ & Std. Deviation \\
\hline AL-NISR AL-ARABI INSURANCE & 6.5435 & 1.69410 \\
JORDAN INSURANCE & 9.0683 & 13.24922 \\
GENERAL ARABIA INSURANCE & 4.0208 & 1.64250 \\
JERUSALEM INSURANCE & 6.7579 & 1.52177 \\
MIDDLE EAST INSURANCE & 9.1574 & 7.47233 \\
THE UNITED INSURANCE & 6.6339 & 5.25918 \\
JORDAN FRENCH INSURANCE & $-1.7504-$ & 13.80950 \\
THE HOLY LAND INSURANCE & 2.4330 & 8.51070 \\
YARMOUK INSURANCE \& REINSURANCE & 10.2813 & 9.96440 \\
GERASA INSURANCE & 1.4847 & 8.17904 \\
ARAB ORIENT INSURANCE & 7.1130 & 2.78407 \\
OASIS INSURANCE/ & -1.81721 & 44.16164 \\
ARAB LIFE \& ACCIDENT INSURANCE & 4.9761 & 4.07448 \\
PHILADELPHIA INSURANCE & 5.2300 & 3.59521 \\
ARAB UNION INTERNATIONAL INSURANCE & 5.9672 & 14.18459 \\
THE NATIONAL AHLIA INSURANCE & 1.6330 & 9.59576 \\
JORDAN INTERNATIONAL INSURANCE & 10.7080 & 5.30459 \\
EURO ARAB INSURANCE GROUP & 3.1810 & 9.66008 \\
ARAB GERMAN INSURANCE & 3.3742 & 3.87376 \\
THE ISLAMIC INSURANCE & 5.5398 & 2.21059 \\
THE ARAB ASSURERS & 4.5115 & 5.24925 \\
ARAB JORDANIAN INSURANCE GROUP & 8.0299 & 7.67815 \\
AL BARAKAH TAKAFUL CO.LTD & 2.7920 & 9.28677 \\
DELTA INSURANCE & 7.2876 & 2.75350 \\
Al-Manara InSSUrance & $-2.7762-$ & 14.81936 \\
Total & 4.1610 & 12.24292 \\
\hline & & \\
\hline & & \\
\hline
\end{tabular}




\section{Macrothink}

Journal of Management Research

ISSN 1941-899X

2012, Vol. 4, No. 2

Table 3. Tolerance and Variance Inflation Factor-VIF

\begin{tabular}{|c|c|c|c|}
\hline & Variables & Tolerance & VIF \\
\hline leverage & & .870 & 1.149 \\
\hline liquidity & & .890 & 1.124 \\
\hline Company age & & .751 & 1.332 \\
\hline Company size & & .763 & 1.311 \\
\hline Management competence & & 0.39 & 2.35 \\
\hline
\end{tabular}

Table 4. The result of ANOVA for testing hypothesis

\begin{tabular}{llllllll}
\hline $\begin{array}{l}\text { Dependent } \\
\text { Variable }\end{array}$ & Source & R Square & Sum of Squares df & Mean Square & F & Sig. \\
\hline Financial & Regression & & 7757.645 & 5 & 1551.529 & 15.328 & $.000^{\mathrm{a}}$ \\
Performance & Residual & 0.37 & 14575.837 & 144 & 101.221 & & \\
& Total & & 22333.482 & 149 & & & \\
& & & & & & & \\
\hline
\end{tabular}

Table 5. Skewness coefficients

\begin{tabular}{lcc}
\hline & Variable & Skewness \\
\hline Leverage & 0.23 \\
Liquidity & 0.65 \\
Company age & 0.19 \\
Company size & 0.89 \\
Management competence & 0.26 \\
\hline
\end{tabular}


Table 6. Results of Multiple Regression Analysis

\begin{tabular}{llllll}
\hline Independent Variables & \multicolumn{2}{l}{ Unstandardized Coefficients } & $\begin{array}{l}\text { Standardized } \\
\text { Coefficients } \\
\text { Beta }\end{array}$ & $\mathbf{t}$ & Sig. \\
\hline (Constant) & $\mathbf{B}$ & Std. Error & Bet & \\
leverage & $-5.130-$ & 2.681 & & $-1.913-$ & .058 \\
liquidity & $5.962 \mathrm{E}-6$ & .000 & .760 & 7.202 & .000 \\
Company age & .013 & .078 & .313 & 3.162 & .046 \\
Company size & $6.138 \mathrm{E}-10$ & .000 & .301 & 1.008 & .994 \\
Management competence & 4.618 & .838 & .686 & 6.509 & .000 \\
\hline
\end{tabular}

